\title{
INFLUENCE OF PLYOMETRICS ON JUMP CAPABILITIES IN TECHNICAL AND AESTHETICAL SPORTS
}

\author{
Gabriela Mlsnová ${ }^{1}$, Jana Luptáková ${ }^{2}$ \\ ${ }^{1}$ Department of Gymnastics, ${ }^{2}$ Department of Sports Kinanthropology, Faculty of Physical Education \\ and Sport, Comenius University in Bratislava, Slovakia
}

Summary: The aim of the study was to examine the effect of plyometric exercises on explosive strength of lower extremities in girls performing of technical and aesthetical sports. Experiment was carried out on three groups; artistic gymnasts $\left(\mathrm{V}_{\mathrm{G}}, \mathrm{n}=15\right.$; age $=12.4 \pm 0.7$ years), fitness girls $\left(\mathrm{V}_{\mathrm{F}}, \mathrm{n}=\right.$ 15 ; age $=13.8 \pm 1.9$ years $)$ and dancers $\left(\mathrm{V}_{\mathrm{D}}, \mathrm{n}=15\right.$; age $=13.8 \pm 2$ years $)$. To check, the control group of general population was involved in the study $\left(\mathrm{V}_{\mathrm{K}}, \mathrm{n}=15\right.$; age $=13.9 \pm 1.5$ years). Following tests on jump ergometer Fitro Jumper were carried out at the beginning and at the end of experimental period: countermovement jump without and with arms swing and 10- second series of repeated vertical jumps. Plyometric program consisted of two plyometric units a week during thirty weeks. The results show that higher improvement in all evaluated tests achieved the group of fitness. In the countermovement jump without arm swing was observed improvement height of the jump $3.4 \pm 1.4 \mathrm{~cm}(\mathrm{p}<0.00001)$, in the countermovement jump with arm swing $5.7 \pm 1.5 \mathrm{~cm}(\mathrm{p}<0.00001)$, in difference of height of the jump between countermovement jump with and without arms swing $2.3 \pm 1 \mathrm{~cm}(\mathrm{p}<0.00001)$, in ten second series of repeated vertical jumps without arms swing in the height of jump $4.2 \pm 1.6 \mathrm{~cm}(\mathrm{p}<0.00001)$ and in power in active take off phase $8.8 \pm 2.2 \mathrm{~W} \cdot \mathrm{kg}^{-1}(\mathrm{p}<0.00001)$. Based on finding the study and in coherence with data from literature, we can conclude the effect of plyometric exercises was effective in combination with specific-strength training. Jumping ability is limiting factor of sport performance in technical and aesthetical sports and implementation of plyometric exercises to the training is highly recommend. The high level of jump capabilities can improve the quality and technique of performance complex acrobatic elements and dance leaps thereby increasing overall evaluation of performance in selected sports.

Key words: explosive strength of lower extremities, artistic gymnasts, fitness, dancers.

DOI 10.1515/afepuc-2017-0008

(C) Acta Facultatis Educationis Physicae Universitatis Comenianae 


\section{Introduction}

According to the classification of sports performance (Schnabel 1988; Dovalil et al. 2002) individual sports are divided into seven groups. The third group consists of technical and aesthetical sports which include artistic gymnastics, fitness and disco free style. These sports are characterized by precision and an aesthetic execution of the performance which are evaluated by judges pursuant to precise rules. The structure of sport performance in individual technical and aesthetical sports is not significantly different. The model of fitness components of Siff (2000) include as well as dynamic explosive strength, speed, stamina, coordination and gymnastic skills.

Explosive power as ability to exert maximum force in the shortest possible time is reflective in carrying out the reflection of dynamic acrobatic elements (Šimonek et al. 2007). The level of explosive strength considered according Jemni (2011) as one of significant criteria in the selection of talented young gymnasts. In all three sport disciplines, which we included in the study, jump capabilities are an important factor of sport performance. Without optimal level of explosive strength gymnasts, fitness and dancer would not be able to perform in the composition technically correct acrobatic elements and leaps, there are basic segments of their performance.

In accordance with literature that suggests there exists key periods of heightened sensitivity to training adaption during the childhood (Viru et al. 1999), recent research has attempted to determine whether the training response to power training is related to age (Lloyd et al. 2012b). The researches collected a range of SSC measurements from 12- and 15years boys, and reported that, following exposure to a four-week training programme, both 12 and 15 years olds made significant improvements in leg stiffness.

Researchers have reported that plyometric training can lead to positive adaptations for children in rebound jump height (Meylan \& Malastesta 2009), maximal running velocity (Kotzamanidis 2006), agility performance (Thomas et al. 2009), vertical jump ability (Feigenbaum et al. 2007), rate-of-force development (Matavulj et al. 2001) and leg stiffness (Lloyd et al. 2012b). In sports, such as gymnastics, fitness and disco free style, is the height of jump prerequisite for effective execution of dynamic acrobatic elements. Therefore, it is important of increasing the level of jump abilities in these sports.

The aim of the study was to find out the influence of 30 week plyometric training program to level of jump capabilities of $12-14$ years old girls in artistic gymnastic, fitness and dance and the results compare with control group of general population. 


\section{Methods}

\section{Subjects}

Research groups consisting of fifteen artistic gymnasts $\mathrm{V}_{\mathrm{G}}$ (age $12.4 \pm 0.7$ years; body height $139.9 \pm 11.8 \mathrm{~cm}$; body weight $35.1 \pm 9.6 \mathrm{~kg}$ ), fifteen fitness girl $\mathrm{V}_{\mathrm{F}}$ (age $13.8 \pm 1.9$ years; body height $152.1 \pm 9.2 \mathrm{~cm}$; body weight $41 \pm 1.5 \mathrm{~kg}$ ), fifteen dancers $\mathrm{V}_{\mathrm{D}}$ (age $13.8 \pm 2$ years; body height $152.2 \pm 10.2 \mathrm{~cm}$; body weight $41.4 \pm 6.9 \mathrm{~kg}$ ) and fifteen girls of general population $\mathrm{V}_{\mathrm{C}}$ (age $13.9 \pm 1.5$ years; body height $154.2 \pm 5.2 \mathrm{~cm}$; body weight $42 \pm 1.2 \mathrm{~kg}$ ).

\section{Experimental design}

The research was carried out in a regular training process at the premises of individual sports clubs. The selected groups attended 30-weeks plyometric training program twice a week aimed to development of jump abilities through plyometric exercises. All exercises were focused on development of explosive strength of lower extremities by gradually increasing the number of repetitions, series, intensity, complexity of the exercises and reducing the rest interval. The same number of training units was implemented in all experimental groups. The exercises were as follow:

1. Jumping rope - legs straight; 1 set, 50 rep., $90 \mathrm{~s}$ rest between next exercises.

2. Squat jumps -2 sets, 10 rep., $60 \mathrm{~s}$ between sets.

3. One leg jump on $20 \mathrm{~cm}$ mat - (L, R); 2 sets, 10 rep., $60 \mathrm{~s}$ rest between sets.

4. Repeated jump on $50 \mathrm{~cm}$ mat -1 set, 30 rep., $120 \mathrm{~s}$ rests between next exercises.

5. Jumping race- 5 sets, 10 jumps, and $60 \mathrm{~s}$ between sets.

Choosing and assessing parameters of selected tests was based on the methods proposed by the authors Zemková \& Hamar (2004). Jump ergometer was applied to assess explosive strength of lower extremities (Hamar 1990). System consists of contact switch mattress, interface and computer equipped with software. Height of the jump $(\mathrm{cm})$ and the power in active take off phase $\left(\mathrm{W} \cdot \mathrm{kg}^{-1}\right)$ were measured in ten second series of repeated vertical jumps. Height of the jump was also measured during single countermovement jump with and without arm swing. The differences of height of the jump between countermovement jump with and without arms swing were also assessed. Except the level of explosive strength of lower extremities, the ability to use elastic energy as one of the important factors affecting the height of jump was assessed as well. The result was calculated as difference of the results height of countermovement jump with and without arm swing by Hamar (1991).

To evaluate statistical significance of differences between groups nonparametric Mann-Whitney U-test was used. To evaluate statistical significance of changes after 
experimental period the nonparametric Wilcoxon t-test was used. Cohen $\mathrm{d}$ was used to calculate effect size which was interpreted as small at cut point of 0.2 , moderate at cut point 0.5 and large at cut point 0.8 (Cohen 1988).

The first data of countermovement jump without arms swing performed on the jump ergometer - the height of the jump was compared (Fig. 1). The best results were achieved in group of artistic gymnasts $\mathrm{V}_{\mathrm{G}}$ at the beginning $22.1 \pm 5.2 \mathrm{~cm}$ and the end of experimental period $24.4 \pm 4.8 \mathrm{~cm}$ which was statistically significant $(\mathrm{p}=0.001)$. Cohen's d was calculated $d=0.46$ what suggests a moderate effect size. The second-best results were achieved in fitness group $\mathrm{V}_{\mathrm{F}}$ which improved from $18.4 \pm 3.7 \mathrm{~cm}$ to $21.8 \pm 2.9 \mathrm{~cm}$. The Increase was statistically significant $(\mathrm{p}=0.00001)$ and Cohen's $\mathrm{d}$ as large effect size was $d=1.02$. The lowest values in height of jump were detected in the experimental group of dancers $V_{D}$. In first measurements $\mathrm{V}_{\mathrm{D}}$ achieved $16.9 \pm 2.9 \mathrm{~cm}$, in second $18.9 \pm 2.7 \mathrm{~cm}$ which was recorded the level of statistical significance $(\mathrm{p}=0.0000029)$. Cohen's $\mathrm{d}$ was calculated $d=0.36$ what suggests a small effect size. In comparing to general population, improvement was not statistically significant $(\mathrm{p}=0.34)$. Cohen's $\mathrm{d}$ was achieved small effect $d=0.33$.

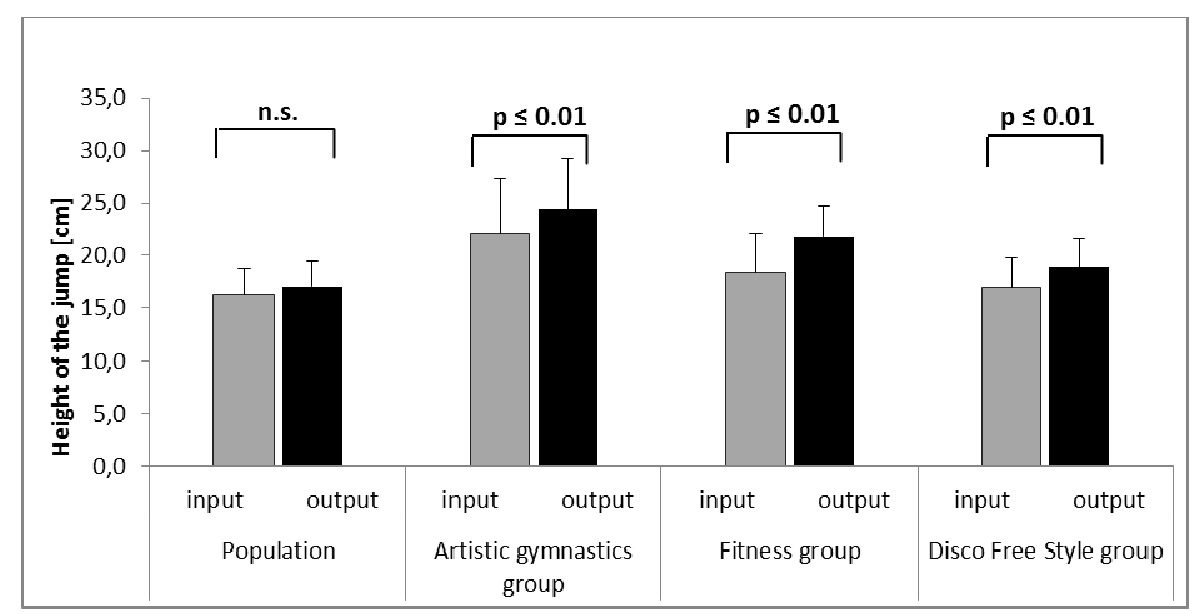

Figure 1

The height of countermovement jump without arms swing in groups

The Figure 2 shown that the best improvement in the height of the countermovement jump without arm swing after experimental period was achieved in fitness group $3.4 \pm 1.4 \mathrm{~cm}$ $(18.5 \%)$. The second highest increase was obtained in group of artistic gymnasts $2.3 \pm 1.4 \mathrm{~cm}$ $(10.4 \%)$, then in group of dancers $2 \pm 1.4 \mathrm{~cm}(11.8 \%)$. The general population has improved by $0.8 \pm 0.4 \mathrm{~cm}(4.9 \%)$. 


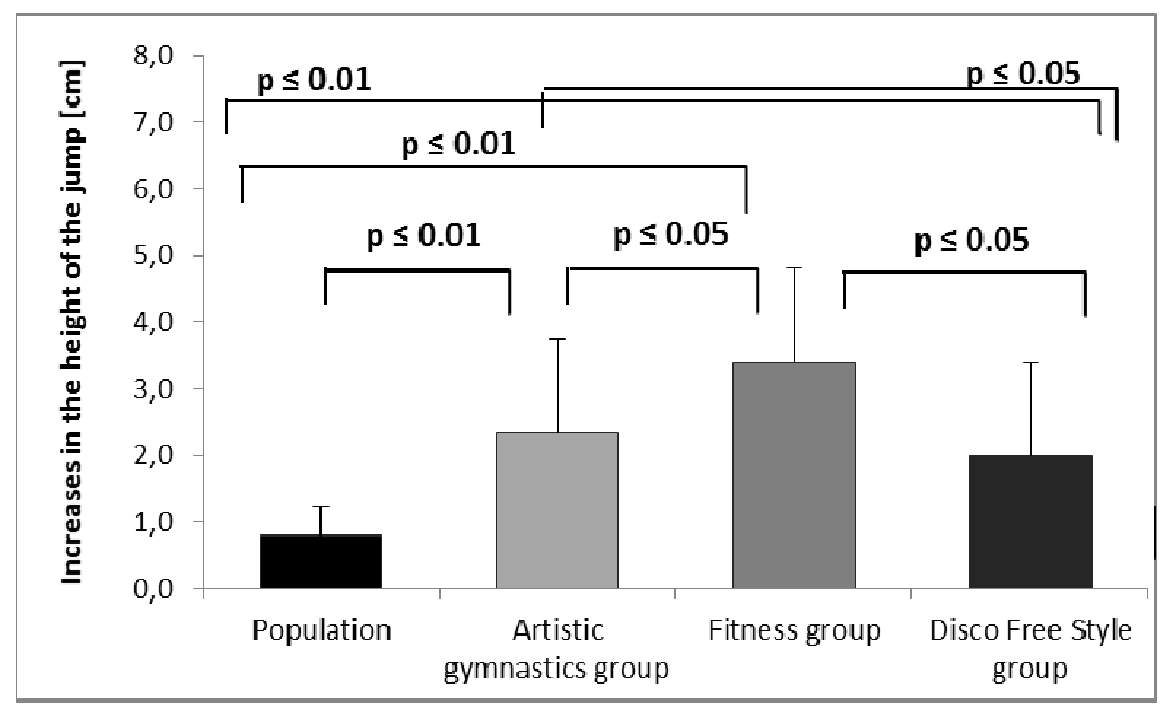

Figure 2

The increases in the height of countermovement jump without arms swing in groups

In the test countermovement jump with arm swing (Fig. 3) the highest values in height of the jump were observed in group of artistic gymnasts $28.8 \pm 6.4 \mathrm{~cm}$ at the beginning and $32.1 \pm 5.1 \mathrm{~cm}$ at the end of experimental period with level of statistical significance $(\mathrm{p}=$ 0.001). Cohen's $d$ was achieved moderate effect $d=0.57$. The fitness group achieved the statistical significance $(\mathrm{p}=0.00001)$ and Cohen's $d=1.55$ as large effect. Dancers obtained $(\mathrm{p}=0.00001)$ and large effect by Cohen's $d=1.21$. At the beginning the fitness group jumped $22.1 \pm 4 \mathrm{~cm}$; group of dancers $21.5 \pm 3 \mathrm{~cm}$ and at the end $\left(\mathrm{V}_{\mathrm{F}}\right) 27.8 \pm 3.3 \mathrm{~cm},\left(\mathrm{~V}_{\mathrm{D}}\right) 25 \pm 2.8$ $\mathrm{cm}$. For comparison, the untrained subpopulations of the corresponding age, were obtained not statistical significance $(p=0.13)$ between $18.6 \pm 3.5 \mathrm{~cm}$ and $19.5 \pm 3.4 \mathrm{~cm}$ values. Cohen's d was calculated $d=0.26$ what suggests a small effect.

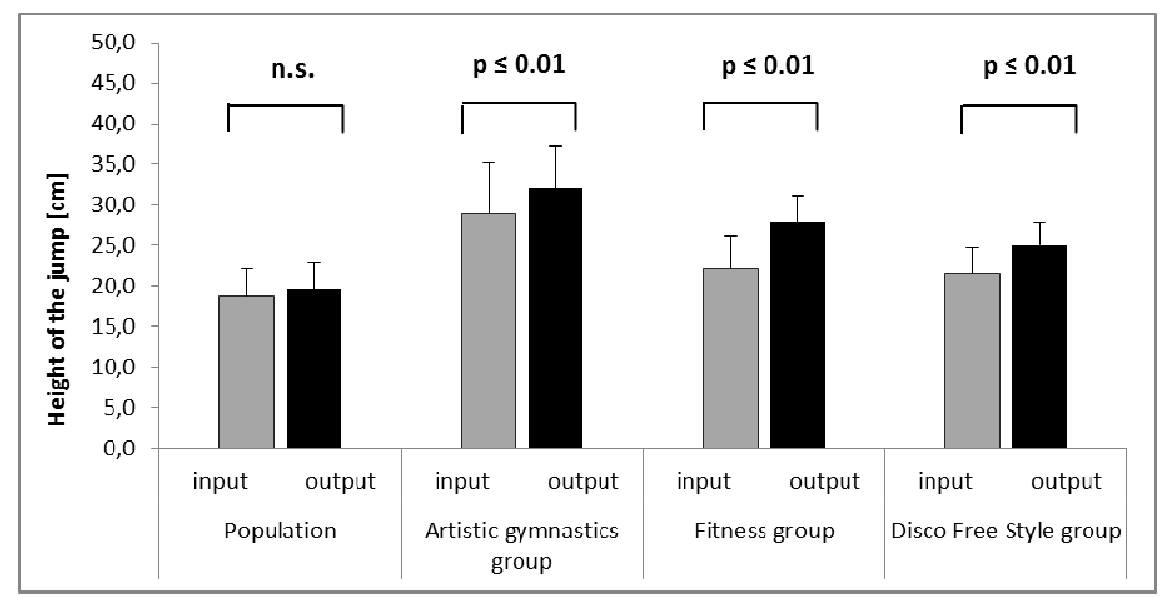

Figure 3

The height of countermovement jump with arms swing in groups 
The greatest increases in the parameter height of countermovement jump with arm swing as shown in Figure 4 in group of fitness $5.7 \pm 1.5 \mathrm{~cm}(25.8 \%)$ were achieved. Slightly lower increases the group of dancers $3.6 \pm 1.7 \mathrm{~cm}(16.7 \%)$ and artistic gymnasts $3.3 \pm 2.1 \mathrm{~cm}$ (11.5\%) obtained. The general population has improved by $0.9 \pm 0.4 \mathrm{~cm}(4.8 \%)$.

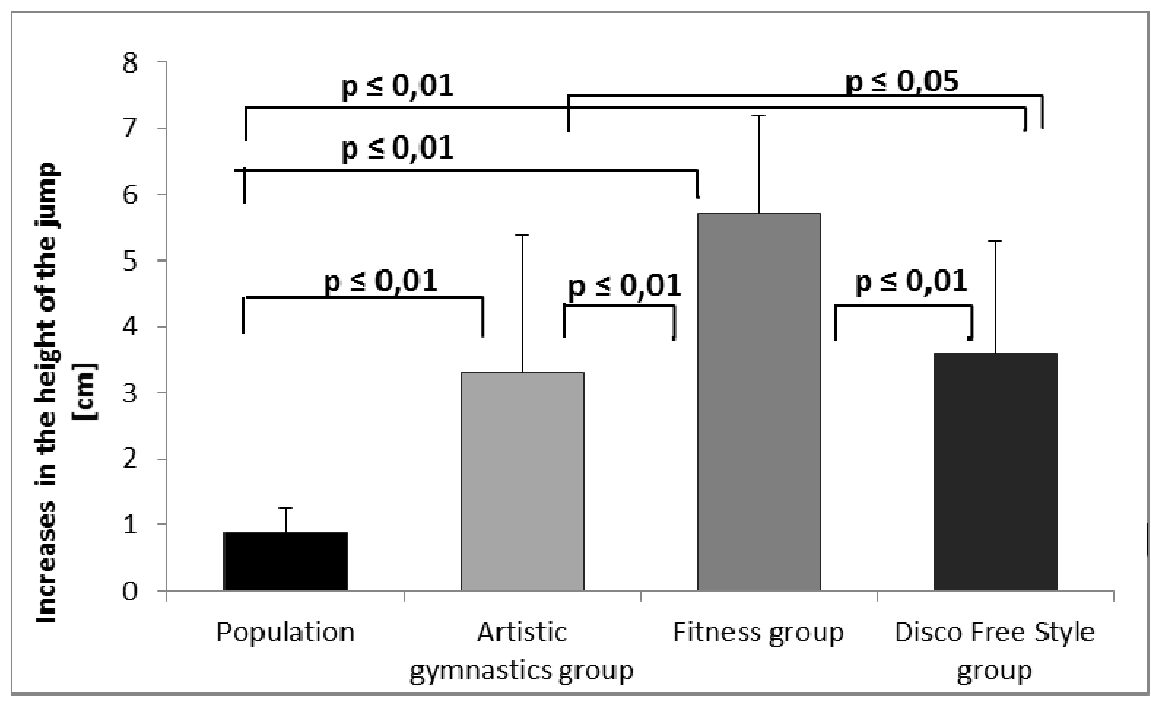

Figure 4

The increases in the height of countermovement jump with arms swing in groups

The best improvement, which was statistically significant $(p=0.00001)$, comparison differences of height of the jump at the beginning $6.8 \pm 1.8 \mathrm{~cm}$ and the end $7.7 \pm 1.3 \mathrm{~cm}$ (Fig. 5) between countermovement jump with and without arms swing $\left(\Delta \mathrm{h}=\mathrm{h}_{2}-\mathrm{h}_{1}\right)$ was observed in the fitness group. Cohen's $d$ was calculated $d=1.02$ what suggests a large effect size. The group of gymnasts achieved also statistical significance $(\mathrm{p}=0.001)$ between difference of 6.8 $\pm 1.8 \mathrm{~cm}$ and $7.7 \pm 1.3 \mathrm{~cm}$. Cohen's d was calculated as moderate effect $d=0.57$. The result in the third experimental group of dancers and control group showed not statistical significance $\mathrm{V}_{\mathrm{D}}(\mathrm{p}=0.78), d=0.77$ as moderate effect and $\mathrm{V}_{\mathrm{C}}(\mathrm{p}=0.58), d=0.05$ as small effect. $\mathrm{V}_{\mathrm{D}}$ improved from $4.6 \pm 2 \mathrm{~cm}$ to $6.1 \pm 1.9 \mathrm{~cm}$ and $\mathrm{V}_{\mathrm{C}}$ from $2.4 \pm 2 \mathrm{~cm}$ to $2.5 \pm 2 \mathrm{~cm}$. 


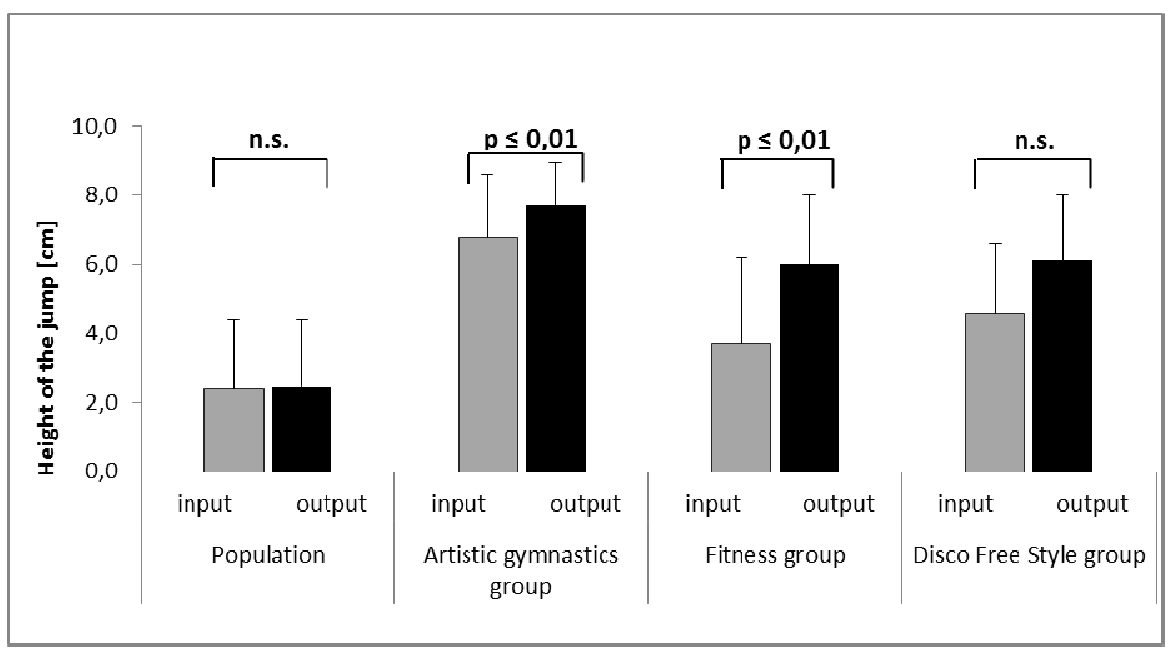

Figure 5

Differences of height of the jump between countermovement jump with and without arms swing in groups

The Figure 6 shown that the best improvement in differences of height of the jump between countermovement jump with and without arm after 30-week plyometric training program was achieved in fitness group $2.3 \pm 1 \mathrm{~cm}(62.2 \%)$. The second highest increase was obtained in group $\mathrm{V}_{\mathrm{D}} 1.6 \pm 1.3 \mathrm{~cm}(34.8 \%)$ then $\mathrm{V}_{\mathrm{G}} 0.9 \pm 1.9 \mathrm{~cm}(13.2 \%)$. The general population has improved by $0.1 \mathrm{~cm} \pm 0.5 \mathrm{~cm}(2.9 \%)$.

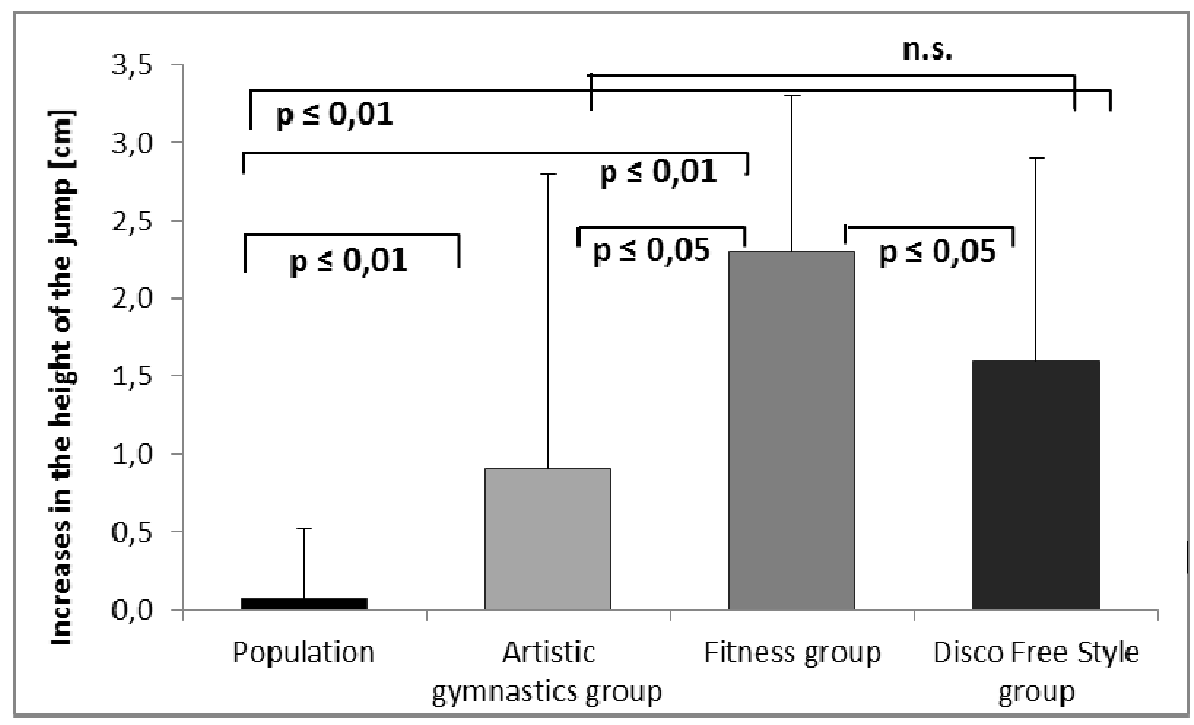

Figure 6

The increases in differences of height of the jump between countermovement jump with and without arms swing in groups

Ten second series of repeated vertical jumps (Fig. 7) showed, that the highest jump at the beginning $24.5 \pm 4.3 \mathrm{~cm}$ and also at the end $25.6 \pm 4.3 \mathrm{~cm}$ was obtained in the group of gymnasts which was statistically significant $(\mathrm{p}=0.002)$. Cohen's $\mathrm{d}$ was calculated $d=0.26$ what suggests a small effect size. The second-best values were achieved in $V_{F}$. They 
improved from $18.1 \pm 3.7 \mathrm{~cm}$ to $22.2 \pm 3.2 \mathrm{~cm}$ which was statistically significant $(\mathrm{p}<$ 0.00001 ) and method Cohen's d calculated a large effect size $d=1.19$. Similarly values in height of jump were detected in the experimental group $V_{D}$ as well as control group. In first measurements $\mathrm{V}_{\mathrm{D}}$ achieved $14.3 \pm 2.1 \mathrm{~cm}$, in second $16.6 \pm 2.1 \mathrm{~cm}$ which was recorded statistical significance $(\mathrm{p}=0.00001)$ and large effect size $d=1.10$. In compared to $\mathrm{V}_{\mathrm{C}} 14.4 \pm$ $3.1 \mathrm{~cm}$ and $14,6 \pm 3.2 \mathrm{~cm}$, was not significant difference $(\mathrm{p}=0.11)$ and only small effect size $d=0.07$ achieved.

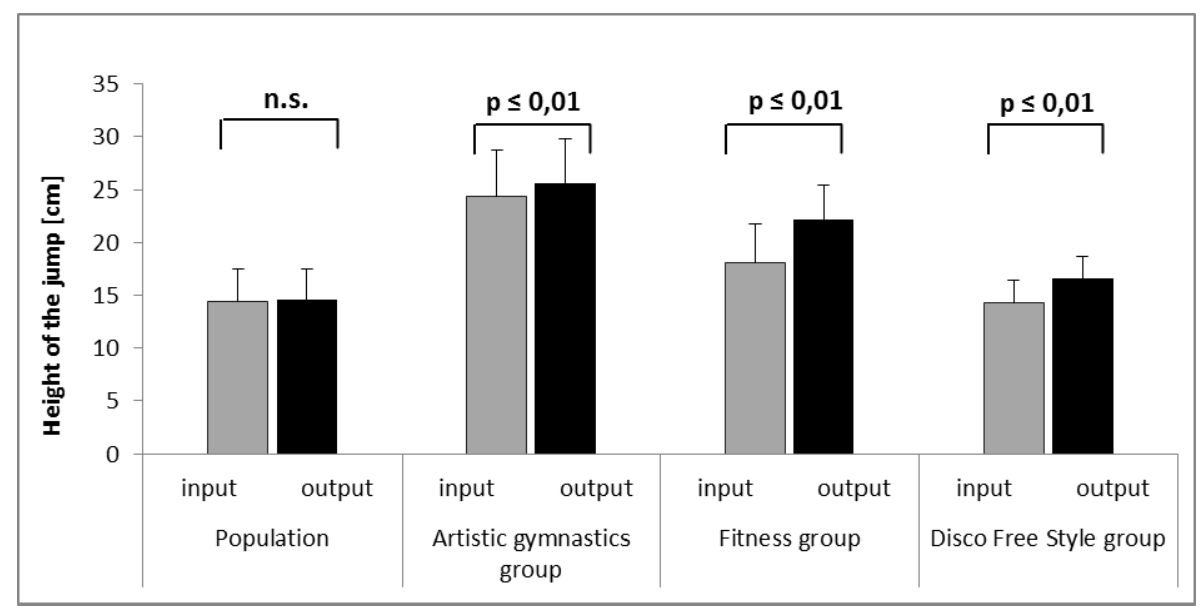

Figure 7

The height of ten second series of repeated vertical jumps in groups

The greatest increases in height of ten second series of repeated vertical jumps as shown in Figure 8 in fitness group $4.2 \pm 1.6 \mathrm{~cm}$ (23.2\%) were achieved. Slightly lower increases $2.3 \pm 1 \mathrm{~cm}(16.1 \%)$ in the $\mathrm{V}_{\mathrm{D}}$ were obtained. Group of artistic gymnasts $1.1 \pm 1 \mathrm{~cm}$ $(4.5 \%)$ and general population $1 \pm 1 \mathrm{~cm}(7 \%)$ has improved almost as.

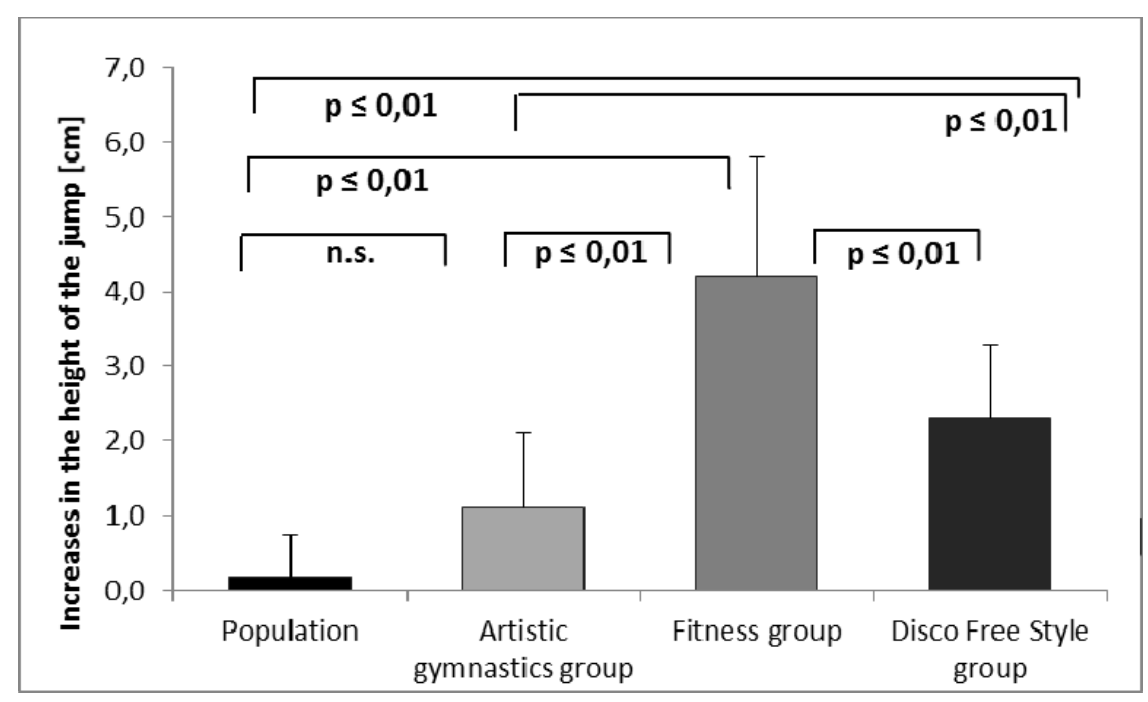




\section{Figure 8}

The increases in the height of ten second series of repeated vertical jumps in groups

In ten second series of repeated vertical jumps (Fig. 9) the highest values in power output in active take off phase in artistic gymnasts $40.3 \pm 7.8 \mathrm{~W} \cdot \mathrm{kg}^{-1}$ in pre- and $42 \pm 7.8$ W.kg ${ }^{-1}$ post-experimental period was observed with level of statistical significance $(\mathrm{p}=$ 0.003 ). Cohen's d was calculated $d=0.22$ what suggests a small effect size. The fitness group achieved the statistical significance $(\mathrm{p}=0.00001)$ and large effect size $d=1.19$. The group of dancers achieved the statistical significance $(\mathrm{p}=0.35)$ and moderate effect size $d=0.54 . \mathrm{V}_{\mathrm{F}}$ improved from $20.6 \pm 7.1 \mathrm{~W} . \mathrm{kg}^{-1}$ to $29.4 \pm 7.7 \mathrm{~W} . \mathrm{kg}^{-1}$ and $\mathrm{V}_{\mathrm{D}}$ from $23.4 \pm 5.8 \mathrm{~W} \cdot \mathrm{kg}^{-1}$ to 26.6 $\pm 6.1 \mathrm{~W} \cdot \mathrm{kg}^{-1}$. Compered the values in $\mathrm{V}_{\mathrm{C}} 19.1 \pm 3.8$ at the beginning and $19.3 \pm 3 \mathrm{~W} \cdot \mathrm{kg}^{-1}$ at the end was not statistically significant $(\mathrm{p}=0.26)$ and only small effect size $d=0.06$ was calculated.

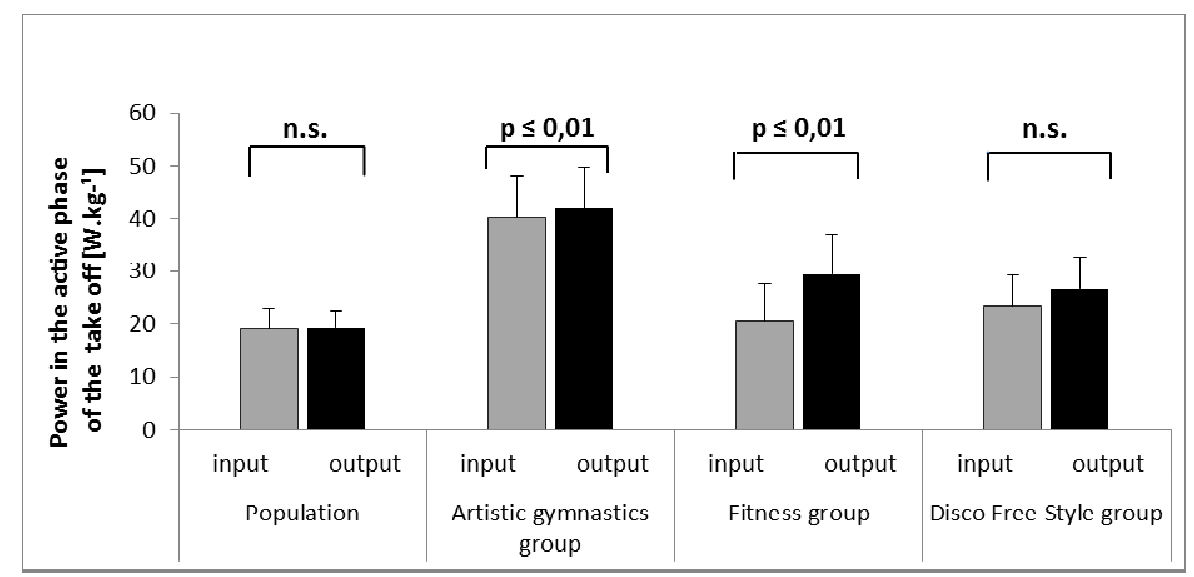

Figure 9

The power output in active take off phase of ten second series of repeated vertical jumps in groups

The Figure 10 shown that the best improvement in the power output in active take off phase after experimental period was observed by fitness group $8.8 \pm 2.2 \mathrm{~W} \cdot \mathrm{kg}^{-1}(42.7 \%)$. The second highest increase $3.2 \pm 2.3 \mathrm{~W} \cdot \mathrm{kg}^{-1}(13.7 \%)$ was obtained in group of dancers then $1.7 \pm$ $1.7 \mathrm{~W} . \mathrm{kg}^{-1}(4.2 \%)$ in the group of gymnasts. The general population only $0.8 \pm 0.7 \mathrm{~W} . \mathrm{kg}^{-1}$ $(4.1 \%)$ has improved. 


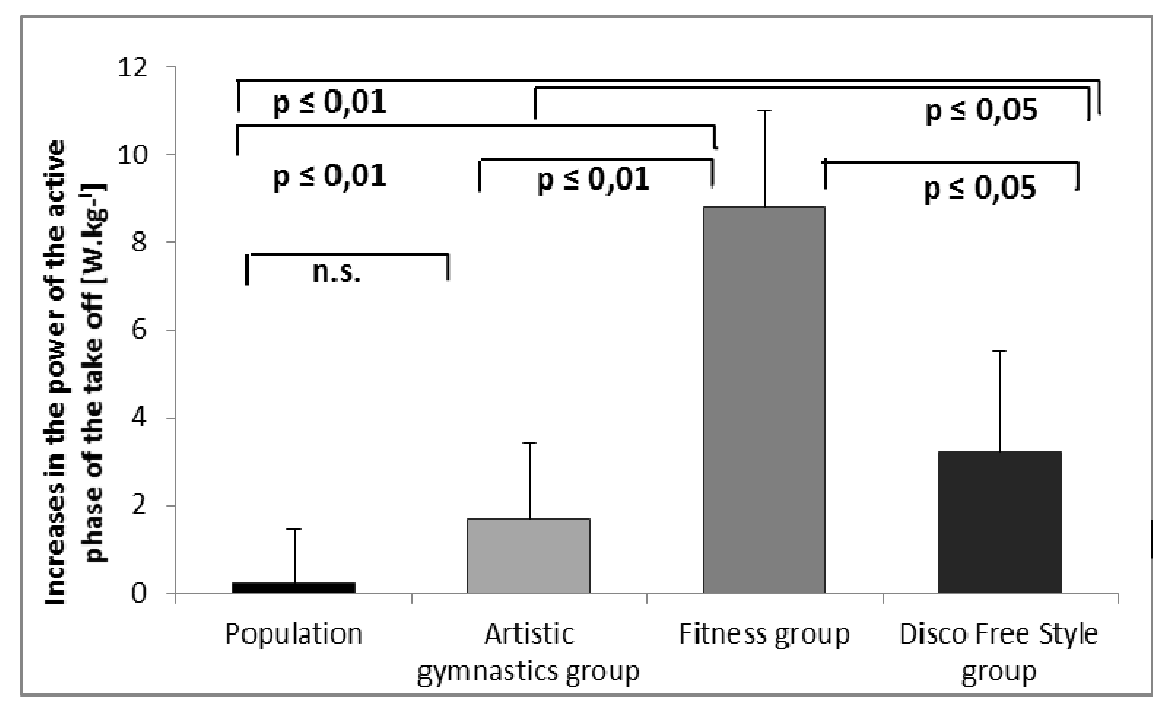

Figure 10

The power output in active take off phase of ten second series of repeated vertical jumps in groups

\section{Discussion}

The study was aimed to determine the effectiveness of 30- week plyometric training program to the level of jump capabilities in technical and aesthetical sports, specifically in artistic gymnastics, fitness and disco free style. The effect of experimental factor was controlled by control group. The results were affected besides plyometrics also by overall training stimulus. The best improvements in all selected tests were achieved in fitness group. They regularly perform gymnastic training with combination of development strength by weightlifting, because except performing fitness routine in competition, they should demonstrate ideal fitness figure. Fatouros et al. (2000) reported that development of jumping abilities by plyometric training with combination of weightlifting is effective. Influence of regularly stimuli of explosive strength of the lower extremities, the fitness group achieved significant increases in all evaluated tests. These positive changes were also reflected in competitive evaluation.

The group of gymnasts also significantly improved in all tests. However, the increases were lower than was anticipated. The reason may be that gymnastic routines contain more dynamic elements and therefore gymnasts should be provided a higher level of jump capabilities compared to the group of fitness and dancers. According to Jemni (2011) gymnasts develop this ability at early age as one of the limiting factor in performance. With similar results were also encountered by Marina \& Jemni (2014). They examined the effectiveness of a combined strength and plyometric training program (experimental period) on jumping performance when compared with a training routine on apparatus (control period). 
The study confirmed that combination of heavy resistance training with high impact plyometric jumps is effective in prepubertal gymnasts, despite their initial high level of physical conditioning.

The group of dancers significantly improved in all tests except difference of height of the jump between countermovement jump with and without arms swing. Similarly, Brown et al. (2007) reported, that group of dancer improved significantly already after 6-weeks plyometric program compared to traditional weight training. Better jumping ability may enable dancers enhance their technique and artistry. The values at the beginning and the end of control period of untrained population of the same age have not shown any statistical improvement in selected tests reflecting the level of explosive strength of lower extremities. To summarize, we have found that more effective methods of development of jump capabilities is combination plyometric methods with specific strength training.

\section{Conclusion}

Based on the results, we recommend, the inclusion of plyometric exercises in combination with specific strength training to increase the level of jump capabilities. These are very important factors of sport performance in technical and aesthetical sports as well as artistic gymnastics, fitness and dance discipline disco free style. Our program of plyometric exercises, performed twice a week, pointed to the effective development of jump capabilities with gradual increase the number of repetition and complexity exercises in combination with development of specific strength abilities. We assume that the effect is the results of adaptive mechanisms at the level of proprioceptive and neuromuscular adaptations, the use of energy accumulated in the elastic tissues in the eccentric phase of muscle contraction and increase of RFD- Rate of Force Development in impact of plyometric exercises. Although positive effect was partially influenced by overall training stimulus in training process.

\section{References}

1. BROWN A, T. WELLS T, M. SCHADE et al., 2007. Effects of plyometric training versus traditional weight training on strength, power, and aesthetic jumping ability in female collegiate dancers. J Dance Med Sci.11(2): 38-44.

2. COHEN, J. 1988. Statistical power analysis for the behavioral sciences (2nd edition). Hillsdale: Lawrence Earlbaum Associates. 
3. DOVALIL, J. et al., 2002. Výkon a trénink ve sportu. Praha: Olympia. ISBN 80-7033$760-5$

4. FAigenbaum, A. D., J. E. McFARLAND, F. B. KEIPER et al., 2007. Effects of a short-term plyometric and resistance training program on fitness in boys age 12 to 15 years. Journal of Sports Science and Medicine. 6: 519-525.

5. FATOUROS, I. G., A. Z. JAMURTAS, D. LEONTSINI et al., 2000. Evaluation of plyometric exercise training, weight training, and their combination on vertical jumping performance and leg strength. The Journal of Strength \& Conditioning Research. 14(4): 470-476.

6. FORD, P., M. DE STE CROIX, R. LLOYD et al., 2001. The Long-Term Athlete Development model: physiological evidence and application. Journal of Sport Science. 29: $389-402$.

7. HAMAR, D., 1990. Výskokový ergometer- uplatnenie pri výbere športovo talentovanej mládeže. In: KOLEKTÍV. Tělesná zátěž u mládeže. Ostrava: Pedagogická fakulta.

8. HAMAR, D., 1991. Výskokový ergometer-princíp a možnosti uplatnenia v diagnostike trénovanosti a tréningovej praxi. Príspevok z pracovného seminára Diagnostika a rozvoj odrazových schopností.

9. JEMNI, M., W. A. SANDS, J. H. SALMELA et al., 2011. The Science of Gymnastics. ISBN 978-0-415-54990-5.

10. KOTZAMANIDIS, C., 2006. Effect of plyometric training on running performance and vertical jumping in pre-pubertal boys. Journal of Strength and Conditioning Research. 20: 441-445.

11. LLOYD, R. S., J. L. OLIVER, M. G. HUGHES et al., 2012b. Effects of 4-week plyometric training on reactive strength index and leg stiffness in male youths. Journal of Strength and Conditioning Research. 26: 2812-2819.

12. MARINA, M., \& M. JEMNI, 2014. Plyometric training performance in elite-oriented prepubertal female gymnasts. The Journal of Strength \& Conditioning Research. 28(4): 1015-1025.

13. MATAVULJ, D., M. KUKOLJ, D. UGARKOVIC et al., 2001. Effects of plyometric training on jumping performance in junior basketball players. Journal of Sports Medicine and Physical Fitness. 41: 159-164.

14. MEYLAN, C. \& D. MALATESTA, 2009. Effects of in-season plyometric training within soccer practice on explosive actions of young players. Journal of Strength and Conditioning Research. 23: 2605-2613. 
15. SCHNABEL, G., 1988. Il fattore tecnico coordinativo. In: MORAVEC, R. et al.: Teória a didaktika výkonnostného a vrcholového športu. Bratislava: FTVŠ UK. ISBN 978-8089075-31-7.

16. SIFF, M., 2000. Strength and the muscular system. Supertraining, 5th ed. Denver: Supertraining Institute, 1-93.

17. ŠIMONEK, J., L. DOLEŽAJOVÁ \& A. LEDNICKÝ, 2007. Rozvoj výbušnej sily dolných končatín v športe. Bratislava: Slovenská vedecká spoločnost' pre telesnú výchovu a šport. ISBN 978-80-89075-32-4.

18. THOMAS, K., D. FRENCH \& P. R. HAYES, 2009. The effect of plyometric training techniques on muscular power and agility in youth soccer player. Journal of Strength and Conditioning Research. 23: 332-335.

19. VIRU, A., J. LOKO, M. HARRO et al., 1999. Critical periods in the development of performance capacity during childhood and adolescence. European Journal of Physical Education. 4: 75-119.

20. ZEMKOVÁ, E. \& D. HAMAR, 2004. Výskokový ergometer v diagnostike odrazových schopností dolných končatín. 1. vyd. Bratislava: Peter Mačura, PEEM. 